\title{
IMPLEMENTASI KEBIJAKAN PEMANFAATAN LAHAN UNTUK PERUMAHAN DAN PERMUKIMAN DI WILAYAH KECAMATAN PAHANDUT DI KOTA PALANGKA RAYA
}

\author{
Implementation of land utilization policy for housing and settlements \\ in Pahandut sub-district, Palangka Raya City
}

\section{Nurhasanah* \\ Imam Mahmud Abillah}

Universitas Muhammadiyah Palangkaraya, Palangka Raya, Central Kalimantan, Indonesia

email:

nurhasanah@umpalangkaraya.ac.id

\section{Kata Kunci:}

Implementasi Kebijakan

Pemanfataan Lahan

Perumahan dan Pemukiman

\section{Keywords:}

Implementation of policies

land utilization

housing and settlements.

\section{Accepted}

January 2015

\section{Published}

April 2015

\begin{abstract}
Abstrak
Penelitian ini bertujuan untuk mengetahui, menjelaskan, mendeskripsikan Impelementasi Kebijakan Pemanfaatan Lahan untuk Perumahan dan Permukiman di Garis tepian Sungai di Kota Palangka Raya. Tipe penelitian yang digunakan adalah metode penelitian kualitatif. Dimana teknik pengumpulan data melalui obesevasi, wawancara mendalam dan dokumentasi. Analisa data menggunkana analisa data kuantitatif, yaitu reduksi data, penyajian data dan penarikan kesimpulan. Adapun data premier dalam penelitian ini adalah SUB Keuangan dan Masyarakat flamboyan Bawah.

Berdasarkan hasil penelitian dpaat disimpulkan bahwa impelmentasi kebijakan pemanfaatan lahan untuk perumahan dan permukiman di Garis Tepian Sungai di Kota Palangka Raya masih belum maksimal, itu karena komunikasi yang telah dilakukan belum optimal, anggara dana untuk mengimplementasikan kebijakan belum memadai, sehingga untuk mengimplementasikan kebijakan belum tercapai secara maksimal. Saran yang dapat diberikan kepada Dinas Perumahan Rakyat dan Kawasan Permukiman Kota Palangka Raya kedepannya agar (I) dapat lebih lagi meningkatkan komunikasi kepada masyarakat (2)meingkatkan anggaran dana untuk mengimplementasikan Perturna Walikota No 8 Tahun 2014 Pasal 2 tentang pemanfaatan lahan.
\end{abstract}

\begin{abstract}
This research aims to know, explain, describe the land utilization policy for housing and settlements in the river bank in Palangka Raya City. The type of research used is qualitative research methods. Where the techniques of collecting data through Obesevasi, in-depth interviews and documentation. Data analysis using quantitative data analysis, data reduction, data presentation and withdrawal of conclusions. The premier data in this study is the flamboyant SUB financial and community below.

Based on the results of the study concluded that the implementation of land utilization policy for housing and settlements in the river bank in Palangka Raya city is still not maximal, that is because the communication has not been optimal, Funds to implement the policy has not been adequate, so to implement the policy has not been reached optimally. Advice that can be given to the people's housing department and the city settlements Palangka Raya in the Future SO (I) can further improve communication to the Community (2) increase the budget of funds to implement the mayor's meeting No. 8 In 2014 article 2 of land utilization.
\end{abstract}

\section{PENDAHULUAN}

Perkembangan dan peningkatkan aktivitas dan jumlah penduduk serta keterbatasan lahan, dapat mengakibatkan pesatnya perkembangan fisik sebuah kota. Pelaksanaan dan pengndalian kota cenderung tidak mampu mengatisipasi pertumbuhan kota tersbut. Akibatnnya, kota tumbuh dan berkembangn secar tidak menentu dan tidak terencana, serta mengakibatkan penurunan kualitas dan fungsi kota itu sendiri. Penurunan kualitas ini diindikasikan oleh semakin banyaknnya penataan kawasan dan tampilan tata ruang yang tidak memperhatikan kesatuan, keharmonisan dan kaidah-kaidah tata ruang. Pertumbuhan dan perkembangan Kota Palangka Raya berawal dari 
kawasan tepian sungai Kahayan, keberadaan kawasan tepian sungai sampai saat ini kurnag memndapat perhatian dalam lingkup penataan ruang kota, karena sungai merupakan bagian belakang yang selalu ditutupi dan dianggap tidak memiliki nilai ekonomis bagi aset wisata kota. Di sisi lain, perkembangan ini sangat betolak belakang dengan sejarah awal terbentuknnya Kota Palangka Raya yang tumbuh dan berkembang dari kawasan tepian Sungai Kahayan.

Permasalahan yang penulis temukan di pemukiman penduduk di Kecamatan Pahandut, Keluaran Langkai yaitu permukiman penduduk disana kurang indah untuk dilihat karena banyak banggunan yang terbuat dari kayu berdempetan-dempetan antara satu dengan lainnya. Bahkan ada juga rumah lanting selain itu di permukiman ini juga terdapt jembatan yang dapat dilalui kendaraan bermotor. Kehidupan keseharian disini masih banyak penduduk yang MCK (Mandi, Cuci dan Kakus) dilakukan di Sungai Kahayan. Beternak babi dan usaha perikanan dengan sistem karemba juga ditekuni oleh penduduk.

Berdasarkan Peraturan Daerah Kota Palangka Raya Nomor 8 Tahun 200 I tentag Rencana Detail Tata Ruang Kawasan (RDTRK) Kota Palangka Raya. Disalah satu pasalnya menyatakan wilayah RDTRK diproyeksikan seluas 17,07 hektare tediri delapan wilayah. Dijelaskan pula pasal lainnya RDTRK untuk kawasan yang berpusat di Kelurahaan Pahandut antara lain dulunya diperuntukan bagi kawasan perumahan, perdagangan/jasa, kesehatan, wisata, lahan cadangan, dan jalur hijau. Sehingga uraian ditas penulis tertarik untuk melakukan peneltian tentang impelementasi kebijakan penataan pemukiman padat penduduk dimana hal ini merupakan masalah sosial yang dapat melahirkan maslaah-maslaah sosial lainnya di luar kendali pemerintah.

Dalam Kamus besar Webster (Wahab,2002:24) merumuskan bahwa implementasi adalah pelaksanaan keputusan kebijakan-kebijakan dasar, biasannya dalam bentuk undang-undang namun dapat pula berbentuk perintah-perintah atau keputusan-keputusan eksekutif yang penting atau badan pengadilan. Menurut pendapat Wibawa (Tangkilisan, 2002:65) mengungkapkan implementasi kebijakan merupakan pengewajahan keputusan mengenai kebijakan yang mendasar, biasanya tertuang dalam suatu undang-undang, namun juga dapat berbentuk intruksi-intruksi eksekutif yang penting atau keputusan perundangan. Indikator yang digunakan dalam penelitian ini adalah menurut Edward III (Soswito,2006) sebagai berikut :

I. Komunikasi

2. Sumber Daya Manusia

3. Diposisi atau Sikap

4. Struktur Birokrasi

\section{Pemanfaatan Lahan}

Pemanfaaatn lahan sangat erat kaitannya dengan konsep Panataan Ruang, Menurut UU No 26 Tahun 2007 Penataan Ruang diklasifikasikan berdasarkan sistem, Fungsu Utama Kawasan, Wilayah Administratif, Kegiatan Kawasan, dan Nilai Stategis kawasan.

\section{Pemukiman Padat Penduduk}

Pemukiman padat penduduk atau sering disebut pemukiman kumuh. Menurut Wastson (Rindjono,2012:27) Permukiman kumuh didefinisiakn sebagai permukiman yang berstatus tidak layak untuk tempat tinggal manusia. Penyebab dari perkembangan pemukiman kumuh, antara lain :

I. Faktor Ekonomi

2. Faktor Geografi

3. Faktor Psikologi

\section{METODOLOGI}

Penelitian ini menggunakan pendekatan Kualitatif. Hal ini karena peneliti ingin melihat keadaaan yang alamiah terjadi dengan menfsirkan fenomena yang terjadi dan dilakukan dengan jalan melibatkan berbagai metode yang ada, yang merujuk kepada pendapat (Moleong,2012:5). Penggalian data akan dilakukan di 
Kecamatan Pahandut dengan observasi partisipan, wawancara mendalam dan dokumentasi.

Kemudian nantinnya yang akan menjadi sumber data primernnya adalah dari pihak Dinas Perumahan Rakyat dan Kawasan Pemukiman Kota Palangka Raya. Dengan dilengkapi studi lapangan serta penelitian yang dilakukan ke pihak kedua,ketiga dan seterusnnya dalam bentuk dokumentasi arsip dan laporan-laporan yang berhubungan dengan permasalahan penelitian.

\section{HASIL DAN PEMBAHASAN}

Berdasarkan Berdasarkan hasil penelitian pada Implementasi Kebijakan Pemanfaatan Lahan untuk Perumahan dan Pemukiman di Garis tepian Sungai di Kota Palangka sebagai berikut :

I. Komunikasi

Komunikasi yang dilakukan dimaksud meliputi Komunikasi yang dilakukan pemerintah kepada masyarakat tentang penataan pemukiman di daerah Flamboyan bawah serta pembangunan destinasi wisata di Flamboyan Bawah. Komunikasi yang telah dilakukan oleh pemerintah kepada masyarakat yang mengetahui tentang kebijakan serta pembangunan destinasi wisata tidak terlalu mengetahui dengan rinci daerah-daerah yang akan ditata kembali serta daerah yang akan dijadikan tempat wisata nantinya.

Cara pemerintah untuk menyampaikan kebijakan penataan permukiman di daerah Flamboyan bawah serta pembangunan destinasi wisata di Flamboyan Bawah memang sudah banyak cara yang dilakukan pemerintah untuk mensosialisasikan kebijakan tersebut. Akan tetapi pembangunan destinasi wisata namun belum banyak diketahui oleh masyarakat secara menyeluruh dan mendetail. Media-media massa yang digunakan pemerintah untuk menyampaikan kebiajakan telah dilakukan tapi masih kurang maksimal.
2. Sumber Daya

Sumber daya yang dimaksud adalh sumber daya dari pegawai yang melaksanakan penataan permukiman di daerah Flamboyan bawah serta pembangunan destinasi wisata di Flamboyan bawah, siapa saja yang berperan dalam pelaksanaan kebiajakan tersebut seta dana untuk implementasikan kebijakan untuk sudah memadai.

Ada 10 pegawai yang ada di bidang bagian pertanahan, perencanaan pengemabngan pemukiman dan pemanfaatan ruang. Namun dinas perkim juga bekerjasama dengan Dinas Pariwisata dan Kebudayaan, Dinas PU dan Panataan ruang serta bekerjasama dengan pihak ketiga. Maka penulis merasa jika dari sumber daya yang ada sudah cukup memadai untuk memgimplementasikan kebijakan tersebut. Anggaran dana untuk mengimplementasikan kebijakan tersebut serta pembangunan destinasi wisata hanya ada sebagaian kecil dari jumlah yang diperlukan untuk mengimplementasi kebijakan serta pembangun destinasi wisata.

3. Disposisi

Dalam penelitian ini disposisi yang dimaksud adalah kebijakan pemanfaatan lahan sudah dilaksanakan sesuai dengan tujuan-tujuan kebijakan, sudah menerima uang ganti rugi dari pemerintah serta sebagaimana sikap waga terhadap kebijakan tersebut.

Pembangunan destinasi wisata di Flamboyan Bawah sedang berjalan namun terasa sangat lambat, sampai saat ini pembangunan yang terlihat baru di turunan Flamboyan serta Guest House. Uang ganti rugi pembebasan lahan baru sebagian warga yang telah menerimanya dan sebagaian lagi belum pahadal seharusnnya uang ganti rugi untuk pembebasan lahan sudah diberikan secepatnnya kepada masyarakat dapat mencari tempat tinggal baru sambil menunggu pembangunan dimulai. 
4. Struktur Birokrasi

Birokrasi yang di maksud adalah ada koordinasi serta pengawasn dengan dinas-dinas terkait untuk mengemplementasikan kebijakan, koordinasi dilakukan serta kinerja yang telah dihasilkan dari koordinasi kepada pihak terkait dinilai memuaskan. Dalam hal ini koordinasi dan pengawasan dilakukan ketika mulai berjalannya pembangunan hanya saja dari pelaksanaan kebijakan belum bisa berjalan secara maksimal karena keterbatasan dana.

Koordinasi dan pengawasn dilakukan ketika mulai berjalannya pembangunan namun untuk pengawasan masih lemah bisa terlihat di turunan flamboyan sudah ada beberapa paving yang rusak dan mulai merenggang serta taman banyak yang terlihat kurang terurus. Bila kita lihat dari apa saja yang telah pemerintah laksanakan hanya sebagian kecilnnya saja dari keseluruhan rencana pembangunan destinasi wisata dan dalam hal pengawasn pun masih dinilai kurang.

\section{KESIMPULAN}

Dari hasil pembahasan dalam penelitian ini, maka dapat disimpulkan bahwa Implementasi Kebijakan Pemanfaatan lahan untuk Perumahan dan Pemukiman di Garis Tepian Sungai di Kota Palangka Raya masih belum maksimal, itu karena komunikasi yang telah dilakukan belum optimal. Anggaran dana untuk mengimplementasikan kebijakan belum meadai. Sehingga untuk mengimplementasikan kebijakan belum tercapai secara maksimal.

Sehingga d iharapkan kepada Dinas Perumahan Rakyat dan Kawasan Pemukiman Kota Palangka Raya dapat lebih lagi meningkatkan komunikais kepada masyarakat melalui sosialisasi, media elektronik dan media cetak secara terus menerus terkait penataan pemukiman di daerah Flamboyan Daerah bawah serta pembangunan destinasi wisata di Flamboyan Bawah.
Kemudian, diharapkan pula kepada Dinas Perumahan Rakyat dan Kawasan Pemukiman Kota Palangka Raya agar dapat menambah anggaran secara bertahap yang digunakan untuk pembebasan lahan untuk mengimplementasikan penataan permukina di daerah Flamboyan Bawah serta pembangunan destinasi wisata di Flamboyan Bawah.

\section{REFERENSI}

Basrowi dan Suwandi. 2008. Memahami Penelitian Kualitatif. Jakarta : PT. Rineka Cipta.

Hill, McGraw. 2003. Dictionary of Environmental science. Malang : Bayumedia Publishing.

Kodoatie, Robert J. 2013. Rekayasa dan manajemen Banjir Kota. Yogyakarta : Andi Offset.

Rindarjono, Mohammad Gamal. 2012. Kajian Permukiman Kumuh dalam Perspektif Spasial. Yogyakarta : media Perkasa.

Sastra M, Suparno dan Marlina, Endy.2005. Perencanaan dan Pengembangan Perumahan. Yogyakarta : Andi Offset.

Tangkilisan, Hesel Nogi S. 2002. Kebijakan \& Manajemen Otonomi Daerah. Yogyakarta : Lukman Offset.

Wahab, Abdul. 2002. Analisis Kebijakan dari Formulasi ke Implementasi Kebijakan Negara. Jakarta : Bumi Aksara.

Worosuprodjo, Suratman. 2007. Analisis Spesial Ekologikal Sumber Daya Lahan di Provensi Istimewa. Yogyakarta. Jurnal Geografi. 